\title{
Tumor Suppressor Candidate 7
}

National Cancer Institute

\section{Source}

National Cancer Institute. Tumor Suppressor Candidate 7. NCI Thesaurus. Code

C147968.

Tumor suppressor candidate 7 ( 2 kb) is encoded by the human TUSC7 gene. This long non-coding RNA plays a role in the downregulation of cell proliferation. 